\title{
RELEVANCE THEORY AND METAPHOR
}

\author{
Esther Romero* \\ Belén Soria** \\ University of Granada \\ Granada, Spain
}

\begin{abstract}
In this article we show the evolution of the view of metaphor in relevance theory and challenge its deflationary account of metaphor, defended from its inception, as loosening in a continuum. In current relevance theory, loose uses not only convey implicatures but also explicatures in which ad hoc concepts appear (CARSTON, 2002, 2010a; SPERBER; WILSON, 2008). These, in the case of metaphor, cause the emergent property issue which, according to them, is solved taking into account that a loose use may be included in a loose use (WILSON; CARSTON, 2008). In addition, the most creative cases have to be explained considering an interpretation route different from ad hoc concept construction (CARSTON, 2010b). These moves generate new problems and thus we argue that metaphorical interpretation can be better explained resorting to metaphorical ad hoc concepts that result from a partial mapping from one conceptual domain into another (ROMERO; SORIA, 2005).
\end{abstract}

Keywords: Relevance Theory. Metaphor. Ad Hoc Concept. Metaphorical Mechanism. Analogy. Pragmatic Derivation.

\section{INTRODUCTION 1}

Relevance theory (henceforth RT) has defended from its inception a deflationary account of metaphor as a consequence of defending a continuity view, on which metaphor is interpreted in the same way as other loose uses (SPERBER; WILSON, $1986 / 1995$, p. 233-237). As Sperber and Wilson (2008, p. 84) have recently stated, "'metaphor" is not a theoretically important notion in the study of verbal communication. [...] there is no mechanism specific to metaphors, and no interesting generalization that applies only to them".

Wilson and her close collaborator Robyn Carston have heartedly supported this deflationary approach. After Carston's $(1997,2002)$ identification of a questionable asymmetry between enrichment and loosening within RT, Wilson and Carston (2007) propose their view of lexical pragmatics that aims at developing a unitary account of how word meanings are adjusted in context. They defend that interpretation, and more particularly metaphor interpretation, often needs ad hoc atomic concept construction.

\footnotetext{
* Tenured lecturer of Logic and Philosophy of Science in the Department of Philosophy I at University of Granada, Spain. PhD in Philosophy of Language. E-mail: eromero@ugr.es.

** Tenured Lecturer of English Language at University of Granada, Spain. PhD in Philology. E-mail: bsoria@ugr.es.

1 This paper is part of the project FFI2011-26418, funded by the Spanish Ministry of Economy and Competitiveness. We are very grateful to Francisco Yus Ramos, editor of this volume, for his useful comments on a previous version of this article.
} 
Furthermore, in response to several critiques on the view of metaphor as loosening, they elaborate arguments in its defence (WILSON; CARSTON, 2008).

To shed some light on their deflationary account of metaphor as loosening in a continuum, we aim to show in section 2 the evolution of the relevance-theoretic approach to metaphorical interpretation as a result of the solutions developed by relevance theorists for some of its initial problems. In particular, we consider their reaction to the questionable asymmetry between enrichment and loosening, the emergent property issue and the inadequacy of the ad hoc concept account of highly creative metaphors. In section 3, we put forward what, in our opinion, the remaining problems are for their deflationary account, especially, for the solutions they proposed for both the emergent property issue and the inadequacy of their ad hoc concepts account for creative metaphors. In this context our second aim arises. This is to show that the remaining problems are really solved when metaphorical interpretation is explained taking into account metaphorical ad hoc concepts that result from an inferential task that involves a partial mapping from a conceptual domain into another (ROMERO; SORIA, 1997/98, 2005, 2007). ${ }^{2}$ This mechanism is specific to metaphor and allows for a homogeneous explanation of the type of ad hoc concept construction that characterizes all cases of metaphorical interpretation including the interpretation of highly creative examples whose metaphorical vehicles (the metaphorically used words) also stand for ad hoc concepts. ${ }^{3}$ This specific explanation of metaphor is not in opposition to the core tenets of RT (in particular to the Principle of Relevance), but it is in opposition to the proposal, included in the development of lexical pragmatics, of metaphor as loosening in a continuum. ${ }^{4}$

\section{AN OVERVIEW OF THE RELEVANCE-THEORETIC APPROACH TO METAPHORICAL INTERPRETATION}

According to Sperber and Wilson (1986/1995), utterance interpretation is guided by the presumption of optimal relevance. This presumption is communicated by every act of overt communication and it is now known as "the Communicative Principle of Relevance" (henceforth PR). The presumption of optimal relevance conveyed by each utterance (metaphorical or not) makes the hearer follow a path of least processing effort and when positive cognitive effects are sufficient to give good reasons for the devoted effort, his expectations of optimal relevance are achieved and he stops. In particular, the presumption of optimal relevance gives him the route by which the hearer must enrich the decoded sentence meaning (or logical form) at the explicit level (by disambiguating, assigning reference, and adjusting meanings if needed), and complement it at the implicit level.

\footnotetext{
2 This proposal is not new and authors such as Richards (1936), Black (1954, 1977), Lakoff and Johnson (1980), Indurkhya (1986, 1992), Kittay (1987), Forceville (1996) or Bowdle and Gentner (2005) among others have defended it.

${ }^{3}$ The feature ad hoc is equivalent to the provisional (occasion-specific) character that we have always claimed for the nature of metaphorical meaning (ROMERO, 1990/91; ROMERO; SORIA, 1997/98).

${ }^{4}$ Authors such as Pilkington (2010, p. 168-170) or Tendahl and Gibbs (2008) also make the claim that a combined framework between the mapping approach on metaphor and Relevance Theory is possible.
} 
The enrichment of the logical form decoded depends on constructing inferentially, by using contextual information, a propositional form that the speaker intends to express. In (1),

(1) [Ann had made it clear that she wanted to settle down and have children and she utters:]

I want to meet a bachelor ${ }^{5}$

(1a) is expressed

(1a) ANN WANTS AT T $_{1}$ TO MEET A BACHELOR

But, even if we saturated the variables, the speaker does not intend to communicate (1a). Ann does not want to meet any bachelor but a bachelor eligible for marriage. Thus, (1b)

(1b) ANN $_{\mathrm{X}}$ WANTS AT T 1 TO MEET A BACHELOR ELIGIBLE FOR MARRIAGE

is an explicature of (1): it is the result of the development of the logical form encoded by the utterance. Guided by PR, the hearer's task to identify (1b) involves a variety of inferential sub-tasks: reference assignment for 'I' $\left(A N_{x}\right)$ and enrichment to specify the type of bachelor she wants to meet (BACHELOR ELIGIBLE FOR MARRIAGE). (See SPERBER; WILSON, 1986/1995, p. 179 and p. 183-193 for more subtasks).

There are other situations where, aiming at optimal relevance, the speaker should not make an utterance whose explicit content is included in the speaker's meaning (SPERBER; WILSON, 1986/1995, p. 233); the propositional content (which is not communicated, so it is not an explicature) is in interpretive resemblance with the thought or thoughts the speaker wants to communicate, and which she merely implicates with her utterance. In this situation, the propositional forms communicated by the utterance are not developments of its logical form. They are implicit communicated assumptions or implicatures (SPERBER; WILSON, 1986/1995, p. 194195). Loose uses of language such as approximations, hyperboles and metaphors are adjustments of this type. The speaker's thought is not interpreted literally but loosely; the propositional content is just implicated.

Let's consider an example of approximation (SPERBER; WILSON, 1986/1995, p. 233). Suppose that Peter earns 797.32 pounds a month. A friend that he has not seen for some years asks about his salary and, instead of answering with (2a), an utterance that interprets his complex thought literally, he responds with (2b), an utterance that interprets her thought loosely.

(2a) I earn 797.32 pounds a month

(2b) I earn 800 pounds a month

\footnotetext{
${ }^{5}$ This and many of the examples of this chapter are adapted from examples used in RT.
} 
From both (2a) and (2b) the hearer can derive, under the described circumstances, the same conclusions about his status, standard of living, life style or whatever the hearer might use his salary as an indicator of. However, the utterance of (2a) takes more processing effort. Thus, given the PR, the speaker will choose to respond with the most relevant utterance compatible with his abilities and preferences, the one that gets the same contextual effects in a more economical way; the false but economical (2b).

This explanation is also applied to metaphor. In the process of the interpretation of (3), the speaker does not intend to communicate the literal and false propositional form represented in (3a).

(3) [Two members of a university department, Mary and Robert, have very different views on how to cope with the recent announcement that their department's funding is to be severely cut. Mary is reluctant to discuss her ideas with Robert, commenting:] Robert is a bulldozer

(3a) ROBERT $_{X}$ IS A BULLDOZER

Rather, its interpretation involves bringing together the encyclopaedic entries for ROBERT $_{\mathrm{X}}$ and BULLDOZER, and thus (3a) is merely the tool to derive communicated contextual implications (implicatures) which can be represented in (3b):

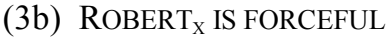 \\ ROBERT $_{X}$ IS STUBBORN \\ ROBERT $_{\mathrm{X}}$ IS PERSISTENT \\ ROBERT $_{X}$ IS INSENSITIVE TO THE FEELINGS OF OTHERS
}

As both the non-literal utterance of (2b) and the metaphorical utterance (3) are explained as cases of loosening, the latter requires no special interpretive abilities or procedures different to those required in other cases of loosening and thus the relevance-theoretic account of metaphor is deflationary.

Relevance theorists have made several important moves that fine-tune this initial approach. The first arises in response to Carston's (1997, 2002) identification of a questionable asymmetry between enrichment and loosening. Utterances such as (1), whose interpretation results in enrichment, express explicatures and utterances such as (3), whose interpretation results in loosening, don't. Nevertheless, enrichment and loosening, as Carston argues, are inferential results of the same pragmatic process that points in different directions: in one case a decoded atomic concept ${ }^{6}$ is enriched (or narrowed) and in the other loosened (or broadened). The new concepts are ad hoc since

\footnotetext{
${ }^{6}$ In RT, concepts are psychological objects and each consists of a label or address. The information stored in memory at a certain conceptual address falls into three distinct types: logical, encyclopaedic and lexical. The logical entry for a concept consists of a set of deductive rules which apply to logical forms of which that concept is a constituent. The encyclopaedic entry includes common assumptions, scientific information, personal and cultural beliefs, idiosyncratic experiences and observations. The lexical entry specifies the phonetic form and syntactic and phonological properties of the linguistic form that encodes the concept (SPERBER; WILSON, 1986/95, p. 86).
} 
they are not lexicalized. ${ }^{7}$ In any case, narrowed and loosened concepts would both form a part of the same kind of communicated propositions by the utterance (CARSTON, 2002, p. 334); both form a part of explicatures.

Narrowing and loosening appear in the interpretation of (1) and (3) respectively as results of the inferential process of interpretation guided by PR. These results affect lexical encoded concepts of the proposition expressed by the utterance, (1a) and (3a), to construct the ad hoc concepts marked, as usual, by asterisks in (1c) and (3c)

\section{(1c) ANN $_{\mathrm{X}}$ WANTS AT T 1 TO MEET A BACHELOR* \\ (3c) ROBERT $_{X}$ IS A BULLDOZER*}

In (1c), there is a case of narrowing where the denotation of the communicated concept, BACHELOR*, includes only the subset of bachelors eligible for marriage; it is a subset of the lexical encoded one. The lexical encoded concept, BACHELOR, is strengthened by means of the property ELIGIBLE FOR MARRIAGE. (1c) is equivalent to (1b). In (3c), there is a case of loosening where the denotation of the communicated concept is wider as a result of weakening the lexical encoded concept, BULLDOZER, by dropping part of its logical entry (a logical or defining feature of it), in this case, the information of being a machine. BULLDOZER* represents the communicated concept and activates the encyclopaedic knowledge of bulldozers that are relevant in relation to Robert, allowing, according to relevance theorists, the implications under (3b). Both (1c) and (3c) are developments of their respective logical forms and are therefore appropriately considered as cases of explicatures. Thus, according to Carston $(1997,2002)$ and later Wilson and Carston (2007, 2008), to interpret loose uses involves conveying explicatures and not just a set of more or less weak implicatures. 8,9

If the result of loosening is also included in the explicature, the continuity extends over literal uses as well as loose uses and thus there is no clear cut-off point between non-metaphorical (literal or non-literal) and metaphorical uses. They are all by-products of the same relevance-guided mutual adjustment process. The pragmatic production of ad hoc non-lexicalized concepts is explained with a unitary account, which is the main claim by Wilson and Carston's lexical pragmatics. ${ }^{10}$

Still, the idea that loosening affects explicatures does not discharge the relevancetheoretic approach from the following problem: loosening cannot explain how every metaphor is understood. While the interpretations of cases such as the utterance of (4) to talk about a rough sea in a storm or such as John's utterance of (5) to talk about the

\footnotetext{
7 The term 'ad hoc concept' was first used by Barsalou (1983) but there are important differences in the way Carston uses this expression. We will show some of them below (see also CARSTON, 2002, p. 367; ROMERO; SORIA, 2012).

8 We agree with the current relevance-theoretic view of metaphor as a use of language whose interpretation affects the explicature or what is said. Nevertheless, as metaphorical ad hoc concepts are characterized in a different way in RT and in our approach, this agreement is limited to the occasionspecific character of ad hoc concepts (ROMERO; SORIA, 2013).

${ }^{9}$ There are more changes in RT due to Carston's work. For more details, see Romero and Soria (2010a).

${ }^{10}$ Nevertheless, as we argue in Romero and Soria (2010b, p. 193), this account cannot explain other pragmatic adjustments such as that involved in metonymies.
} 
addressee's younger sister, Caroline, who is manifestly not a princess, are explained by means of loosening and by means of a combination of narrowing and loosening respectively, the interpretation of (3) isn't.

\section{(4) The water is boiling \\ (5) Caroline is a princess}

Let's see the differences between the utterances of examples such as (4) or (5) and (3). For (4), a case of loosening without narrowing, the properties are selected by the criterion of literal applicability to the topic [BUBBLING, SEETHING, EMITTING VAPOUR, etc.]; the denotation of BOILING is a subset of BOILING*. (5) requires both narrowing and loosening. John is concerned about Caroline properties such as her haughty, spoilt ways. These properties reduce the denotation of the PRINCESS concept to those princesses who have haughty and spoilt ways. As her status in a royal family is lost, the PRINCESS* concept does not include the logical property of PRINCESS: being a female member of a royal family. Thus, its denotation is also broadened to a set that includes female persons who are not members of a royal house and have haughty and spoilt ways, properties that apply literally to Caroline. The denotation of PRINCESS intersects with that of PRINCESS*. For (4), a mere case of loosening, and for (5), a case of narrowingloosening, the properties are selected by the criterion of literal applicability to the topic.

By contrast, for the metaphorical interpretation of cases such as (3), a category crossing metaphor, ${ }^{11}$ there are no properties of the concept related to the metaphorical vehicle (BULLDOZER) that can be attributed literally to the topic $\left(\right.$ ROBERT $\left._{\mathrm{X}}\right)$. Neither the denotation of BULLDOZER is a subset of that of BULLDOZER* nor it intersects with it. These denotations are disjoint sets with no common items. ${ }^{12}$ Our encyclopaedic knowledge of bulldozers, those large machines used for clearing earth, rocks, rubble, etc., is unlikely to include the information that they may be forceful, stubborn, persistent, and insensitive to feelings and viewpoints of others. Then, these properties of bulldozers that are literally attributable to Robert should emerge for BULLDOZER* since they are not included in the encyclopaedic information associated with BULLDOZER. ${ }^{13}$ Wilson and Carston (2008, p. 1) call this problem "the emergent property issue," taking into account that they consider emergent properties as properties "which are neither standardly associated with the individual constituents of the utterance in isolation nor derivable by standard rules of semantic composition." The question, applied to a metaphor such as (3), is

\footnotetext{
11 Examples of this type are called "category crossing metaphors" by Wilson and Carston who characterize them as "necessary falsehoods, where a literal interpretation of the predicate is incompatible with a literal interpretation of the subject" (2008, p. 14).

${ }^{12}$ For us, this happens in all types of non-conventional metaphorical utterances. There are no properties related to the concept expressed by its metaphorical vehicle that are also literally applied to the topic in the same sense. For more details, see below.

${ }^{13}$ This problem of category crossing metaphors also arises in metonymic utterances where the denotation of the head of the noun phrase used metonymically changes completely. Carston (2010a, p. 244) admits that "metonymic uses present an interesting challenge since they seem to result in an ad hoc concept which contributes to explicature (truth-conditional content) but they are not instances of narrowing or broadening of the encoded lexical concept."
} 
[...] how do the properties of forcefulness, stubbornness, insensitivity (etc.) 'emerge' in the course of understanding (9a) [(3) in this paper], when the encoded concept BULLDOZER is literally inapplicable to Robert, and the properties the speaker is understood as attributing to Robert are not listed in the encyclopaedic entry of BULLDOZER (and so on for the other examples)? (WILSON; CARSTON, 2008, p. 16)

The difficulty in answering this question raises a challenge for Wilson and Carston (2008, p. 19) who need to justify the move from encoded concept to communicated concept and from communicated concept to implicatures "without appeal to special interpretive mechanisms not required for ordinary non-metaphorical utterances." This challenge might be met if the following question is answered:

\begin{abstract}
how can there be a genuinely inferential transition from the premise that the speaker uttered the sentence 'Robert is a bulldozer' to the conclusion that the speaker asserted that Robert is a BULLDOZER* and implicated that he is forceful, stubborn, persistent, insensitive to the feelings of others (etc.) (WILSON; CARSTON, 2008, p. 15)
\end{abstract}

The inferential transition would have to go from the speaker's utterance, (3), to the contextual implications, indicated in (3b), through the explicit content (3c). To justify that inferential transition they suggest that as a result of the mutual adjustment process of explicit content, context and contextual implications,

Mary might therefore be understood as asserting that Robert is a BULLDOZER* (where a BULLDOZER* is POWERFUL*, CRUSHING*, GOES AHEAD REGARDLESS OF OBSTACLES*, etc.) (WILSON; CARSTON, 2008, p. 33)

Relevance theorists try to explain how properties emerge for bulldozers by saying that BULLDOZER* acquires ad hoc properties. These asterisk-properties (POWERFUL*, CRUSHING*, GOES AHEAD REGARDLESS OF OBSTACLES*) are derived metaphorically from some properties associated with the encoded concept BULLDOZER: some of the encyclopaedic information associated with the encoded concepts has itself to be metaphorically interpreted. This means that "the comprehension process involves a metaphor inside a metaphor (or a loose use inside a loose use)" (WILSON; CARSTON, 2008, p. 16) and this entails that other contextual assumptions have to be involved in the inferential transition. The inferential transition would be from $(3 c)$ to $(3 b)$ taking into account the contextual assumptions (3d).

(3c) ROBERT ${ }_{X}$ IS A BULLDOZER*

(3d.1) A BULLDOZER* IS POWERFUL, CRUSHING, GOES AHEAD REGARDLESS OF OBSTACLES

(3d.2) A BULLDOZER* IS POWERFUL*, CRUSHING*, GOES AHEAD REGARDLESS OF OBSTACLES*

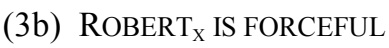

ROBERT $_{\mathrm{X}}$ IS STUBBORN

ROBERT $_{X}$ IS PERSISTENT

ROBERT $_{X}$ IS INSENSITIVE TO THE FEELINGS OF OTHERS 
Thus, the first loosening affects BULLDOZER, as can be seen in the step from (3a) to $(3 \mathrm{c})$. The second loosening affects the properties that characterize BULLDOZER*, as can be seen in the step from $(3 \mathrm{~d} 1)$ to $(3 \mathrm{~d} 2)$. This explanation, according to relevance theorists, is of use to meet the challenge that the emergent property issue raised for the continuity view. If emergent properties could be processed as a loosening within loosening, the emergent properties (encyclopaedic properties*) would be encyclopaedic properties of the encyclopaedic properties associated to the metaphorical vehicle that would be attributed literally to what we are talking about. For (3), the properties are selected by the criterion of metaphorical applicability to the topic, producing emergent properties or encyclopaedic properties*. The latter would be derived without any appeal to a special interpretive mechanism. This explanation means that the denotation of BULLDOZER is eventually a set enclosed completely in the wider denotation of BULLDOZER*. If in the interpretation of (3), emergent properties that apply literally to both the denotation of the metaphorical vehicle and to the topic appear for the concepts associated to the metaphorical vehicle, these properties will enable literal bulldozers to fall under BULLDOZER*.

Another important and recent move in RT is made by Carston (2010b) as an answer to the problem that arises because ad hoc atomic concepts derived by loosening cannot account for innovative or extended metaphors. As we told her (ROMERO; SORIA, 2010b), sometimes complex concepts (typically expressed by phrases) must be pragmatically adjusted in order to determine their contribution to truth-conditional content (explicature). This task cannot be achieved by means of lexical pragmatics in which only the pragmatics of atomic lexicalized concepts is considered. What we have called "phrasal pragmatics" should be added to account for complex (hence compositional) concepts (and not only atomic concepts) as inputs of pragmatic adjustments (2010b, p. 189-190). In (6),

(6)[An American academic, Morris, goes to a British institution as a visiting professor, and A says about him:] In all modesty Morris imagined he must be the biggest fish in this backwater

BIGGEST FISH IN THIS BACKWATER needs fine-tuning as a whole. It is the literal complex concept that must be metaphorically adjusted to form the proposition expressed by the utterance (6). This is very different from considering FISH as an independent input of this pragmatic process that would result in the ad hoc atomic concept, FISH*. FISH* would have some properties that can be applied to academics but these properties are irrelevant to understand (6). The speaker of (6) is not interested in the encyclopaedic properties of FISH, but in the encyclopaedic properties of the phrasal complex concept BIGGEST FISH IN THIS BACKWATER such as the expressed by 'a fish which can eat all the others but which is not itself very big since it can swim in a backwater'. When this is attributed metaphorically to Morris, it permits the reader to know how he is feeling. Only the metaphorical ad hoc concept [BIGGEST FISH IN THIS BACKWATER]* allows understanding how Morris is, to wit, the person who conceives himself as the most powerful academic in this not very important British institution, while FISH* doesn't (ROMERO; SORIA, 2010b, p. 190-191). 
As a reply to our observation, nevertheless, Carston (2010a, p. 253) says that it is not entirely clear to her that this example involves a phrasal input. She considers that the phenomenon most apt to draw one in the direction of phrasal ad hoc concepts is extended metaphor. For her, however, the phrase in italics in (6) "could be argued to be just as readily understood as THE BIGGEST FISH* IN THIS BACKWATER*, that is, as involving two instances of lexical adjustment/transfer." Still, later in her chapter, she recognises the difficulty to maintain that what happens in the interpretation of innovative or extended uses of metaphor could be explained by this type of adjustment where practically every concept would need broadening (2010a, p. 257). If so, to interpret (7), the logical entries included in the concepts encoded by 'lighthouse', 'rescued' and 'mariners' should be dropped and their respective denotations broadened.

\section{(7) Love is the lighthouse and the rescued mariners}

This seems unlikely to her and thus she argues for a second interpretation route for innovative, literary or extended metaphors. Indeed, in Carston (2010b), she suggests that understanding these may not be a matter of forming ad hoc atomic concepts but a different kind of pragmatic process altogether, a different interpretation route in which the literal meaning is not dispensed with. Unlike what happens in the interpretation of ordinary cases such as (3), (4) and (5), in innovative, literary or extended metaphors, the literal interpretation is metarepresented as a whole so that what we have is a representation of an imaginary state of affairs from which implicatures (and other nonpropositional effects) can be derived. This is what happens in the interpretation of (7), for which "there is no explicitly communicated propositional content other than the literal meaning itself represented within the mental equivalent of scare-quotes" (CARSTON, 2010b, p. 307). In addition, she highlights that the most important effects in this type of metaphors are often imagistic non-propositional effects.

\section{REMAINING CHALLENGES: TOWARDS A COMBINED MODEL OF MAPPING AND RELEVANCE}

The major problem in relation to the approach of metaphor as loosening in a continuum is, in our opinion, related to its explanation of the emergent properties. For relevance theorists, emergent properties appear in category crossing metaphor interpretation. For this kind of metaphor, there are no encyclopaedic properties related to the concept linguistically encoded by the metaphorical vehicle which are literally applied to its topic and which contribute to the intended meaning of the metaphorical utterance. This fact, according to the relevance account, triggers the requirement of emergent properties for the metaphorical vehicle so that they can be literally applied not only to its denotation but also to the topic. As we mentioned in the previous section, they propose to account for emergent properties considering a loose use inside a loose use. The first loosening involves that the logical entry of the lexical concept encoded by the metaphorical vehicle has to be dropped and some of its encyclopaedic properties 
have to be activated. The embedded loosening involves that the encyclopaedic properties activated by the first loosening have to lose their logical properties as well and trigger some encyclopaedic assumptions that apply literally to both topic and vehicle.

However, this relevance-theoretic strategy to interpret category crossing metaphors does not meet the challenge raised by the emergent property issue. One of its problems is that if there are no encyclopaedic properties of the encyclopaedic properties of the source concept literally applicable to the denotation of both the source concept and the topic, we should, to be coherent with the relevance-theoretic solution, appeal to a metaphorical use of the former. In that case, as there would be no encyclopaedic assumptions literally attributable to Robert for the asterisk (metaphorical) properties, emergent properties should have to appear as a result of properties interpreted again metaphorically. Having reached a certain point, it does not seem likely that we can go on interpreting metaphorically the encyclopaedic properties of the encyclopaedic properties of the encyclopaedic properties without a substantial effort which might preclude relevance. ${ }^{14}$

This problem, in addition, is related to a more serious one: the problem that there is nothing we can do within the interpretive mechanism of loosening and its recursive application to the encyclopaedic properties to turn the properties literally associated to a bulldozer into properties literally associated also to Robert. According to Wilson and Carston, we interpret metaphorically those encyclopaedic properties of BULLDOZER* indicated in $(3 \mathrm{~d} 1)$ to obtain those indicated in $(3 \mathrm{~d} 2)$, but how can we go from POWERFUL*, CRUSHING*, GOES AHEAD REGARDLESS OF OBSTACLES* to FORCEFUL, STUBBORN, PERSISTENT, INSENSITIVE TO THE FEELINGS OF OTHERS, which are properties that, as Carston (2002, p. 354) also says, describe a kind of human temperament of Robert when he is metaphorically described as a bulldozer? Why does ROBERT $\mathrm{X}$ IS FORCEFUL follow from ROBERT $\mathrm{X}_{\mathrm{X}}$ IS A BULLDOZER* and A BULLDOZER* IS POWERFUL*? What is the encyclopaedic property of POWERFUL* that is literally applied to a human temperament and a heavy machine? Is it FORCEFUL? Bulldozers do not have the property of being forceful or of being stubborn, etc. and the communicated concepts BULLDOZER* or POWERFUL* cannot activate them. Even after the loose use within the loose use by means of which POWERFUL*, CRUSHING*, GOES AHEAD REGARDLESS OF OBSTACLES* are included in the pragmatic adjustment, the entities in the world that fall under the two concepts BULLDOZER* and BULLDOZER still comprise disjoint sets. Loosening within loosening is not a solution to the emergent property issue.

But if this is so, there is no reason to choose the property POWERFUL from the encyclopaedic information associated with the encoded concept BULLDOZER since it cannot be used as an assumption to get to the expected contextual implication ROBERT $_{\mathrm{X}}$ IS FORCEFUL. Another problem then appears: to know what properties related to the metaphorical vehicle are going to undergo loosening or to know how the hearer can obtain (3d1), the properties that have to be interpreted metaphorically.

\footnotetext{
${ }^{14}$ To avoid this problem, relevance theorists should have to argue that every metaphor has to get rapidly a literal property that applies to both topic and vehicle literally or even that every category crossing metaphor can be explained appealing only to a loosening of a loosening.
} 
The reason why, in our opinion, it is hard for relevance theorists to solve the emergent property issue is that they think that emergent properties not only have to be attributed to the topic but also to the denotation of the metaphorical vehicle. This assumption, nevertheless, is not assumed in all the approaches on metaphor. When the speaker uses 'bulldozer' metaphorically in (3), he is not talking about a bulldozer but about Robert, a person, and he is not interested in applying this expression to things that it literally applies to. Nothing is meant to be conveyed about literal bulldozers in the interpretation of (3) and much less does the speaker intend to apply a property of human temperament to a bulldozer. In its metaphorical sense, this predicate is not applied to certain machines, the metaphorical meaning of its properties does not have the requirement that they have in $\mathrm{RT}$ of being applicable to both a tractor fitted with caterpillar and Robert, a person. As Goodman (1979, p. 125-126) said: "a metaphorical application [the collection of things denoted by a word or other label] of a term is normally quite different from the literal application. Applied literally, the noun "sapphire" sorts out various things including a certain gem but no lake; applied metaphorically (in the way here in question ["The lake is a sapphire"]) it sorts out various things including a certain lake but no gem." Similarly, applied metaphorically 'bulldozer' in (3) is used to denote a certain type of man but no tractor. The latter should be excluded from the denotation of the intended concept. ${ }^{15}$ If this is so, the relevancetheoretic strategy of loosening inside of loosening to interpret category crossing metaphors would not be motivated.

Although the derivation of metaphorical emergent properties as new properties for the metaphorical vehicle that apply to both its literal denotation and the topic is considered by Wilson and Carston (2008, p. 17) as an issue for all pragmatic accounts of metaphor, it is really only a problem for the theoretic explanation of metaphor as loosening in a continuum. From the mapping approach, as we are going to show, this issue does not appear because what the speaker intends to communicate with (3) cannot be that Robert is an entity with both human and bulldozer properties. As bulldozers are excluded from the denotation of the communicated concept, no properties need to emerge for them. In the mapping account, bulldozer is just the source domain to describe the target analogically.

Obviously, to interpret (3), the properties indicated in (3d1), [POWERFUL, CRUSHING, GOES AHEAD REGARDLESS OF OBSTACLES], may be chosen as part of the pragmatic adjustment (ROMERO; SORIA, 2007, p. 151) but as it is admitted in RT, they do not form a part of the communicated concept. The selected properties must be

\footnotetext{
${ }^{15}$ This point has been explicitly recognized by Carston $(2012, \mathrm{n} 4)$ who says that it can be resolved if it takes into consideration that "metaphorical use inevitably involves concept narrowing as well as broadening" (CARSTON; WEARING, 2011, p. 293). Although, as Carston and Wearing recognize, it is still a preliminary account and some its consequences remain to be seen, it is important to note that it marks a revision of Carston's previous defence of metaphor as loosening in a continuum (WILSON; CARSTON, 2007, 2008), since they admit that there is a discontinuity between metaphors and other loose uses. It is a critical departure from the established loose use account of orthodox RT in an attempt to explain cross-category metaphors and it means that the emergent property issue cannot be sorted out by means of loosening within loosening. This new move by Carston gives support to some of our criticisms to the loosening account (ROMERO; SORIA, 2007) but still relies on loosening for its explanation and cannot escape many of its problems.
} 
interpreted metaphorically. Still, this does not mean that they have to undergo loosening again. In our opinion, (3d1) can be selected as a result of matching a system of connected relations from one domain (source) to another (target). The meaning of ( $3 \mathrm{~d} 1$ ) will change according to a mapping that is possible due to the speaker's ability to think about relational patterns. This ability is known as analogy ${ }^{16}$ and the main aim of the mapping approach is to explain how the analogical reasoning that intervenes in the metaphorical interpretation is reached.

In the mapping approach, a metaphor cognitively links two separate domains, by using the language appropriate to one of them as a lens through which to observe the other and only items belonging to the target domain are included in the denotation of the ad hoc concept that results from the pragmatic adjustment. When a metaphor is interpreted, at least two concepts represented by two domains are identified. One of the concepts is the topic we are talking about and is represented by the target domain. The other concerns what we attribute to the topic and is represented by the source domain, the domain to which the terms that constitute the metaphorical vehicle belong. Let's consider (8), a different metaphorical utterance of the same expression used in (3).

(8) [Two members of a university department, Mary and John, are discussing how to settle a department issue. John, the head of department, is reluctant to propose their common view himself and he asks Mary if she believes that Robert could help. Mary answers affirmatively and adds:] Robert is a bulldozer

In (8) the target domain describes the concept ROBERTX and the source domain describes the concept BULLDOZER. These domains consist of a vocabulary and a set of sentences which specify how the vocabulary terms express the information associated with the concept (what in RT is the information of the logical and encyclopaedic entries of a concept). They express the stored information that gets activation in the context of the utterance such as $\left[1_{s}\right]-\left[6_{s}\right]$ for the source domain, bulldozer, in $(8)$ and $\left[1_{t}\right]-\left[5_{t}\right]$ for the target domain, Robert:
$\left[1_{\mathrm{s}}\right]$ Bulldozers are large machines
$\left[2_{s}\right]$ Bulldozers are powerful
$\left[3_{\mathrm{s}}\right.$ ] Bulldozers go ahead clearing earth, rocks, rubble, etc. in their way
$\left[4_{s}\right]$ Bulldozers have the power to clear obstacles
$\left[5_{\mathrm{s}}\right]$ Bulldozers can be used to clear obstacles
$\left[6_{s}\right]$ When a bulldozer is used, the user becomes powerful, etc.

$\left[1_{t}\right]$ Robert is a member of a university department

$[2 \mathrm{t}]$ Robert is forceful in his arguments

[3 $3_{t}$ Robert takes his ideas ahead without considering other opposing views in department meetings

[4t] Robert has the power to overcome difficult opponents

[5] Robert does not surrender to difficulties, etc.

\footnotetext{
16 Theoretical and empirical evidence of its role in cognition and more specifically in novel metaphor interpretation has been provided by psychologists such as Gentner and her colleagues (GENTNER, 1982, 1983; GENTNER et al., 2001).
} 
The interpretation of (8) entails finding a structural alignment between these domains so that the target domain is described in terms of the source domain. This alignment is characterized, among other things, by structural parallelism (consistent, one-to-one correspondences between mapped elements). A set of sentences from the source domain, $S$, are mapped to sentences in the target domain. The mapping is made by a partial function $F$ from terms belonging to the bulldozer domain, to terms that belong or will belong to the Robert domain and by the selection of a subset of sentences of the former, $S$, which are coherently transformable by $F$ to information associated with the latter. $S$ is transformable by $F$ when each of the terms of $S$ either belongs to $F$ and is mappable to the vocabulary of the target domain or belongs to the vocabulary of this domain directly. The transformation of $S$ results in sentences similar to those included in $S$ but only with target domain terms, Robert domain terms, and the transformation is justified if the transformed source domain sentences are coherent with the set of sentences of the actual target domain. They are coherent if their union is true under at least one model or world. Coherence is an inferential requirement for mappings to determine what features of the source domain fit or correspond to the features of the target domain: we can only transfer information that does not make our conception of the actual target domain incoherent.

Metaphors describe the target domain in terms of the source domain, selecting, highlighting, and organizing certain features of the target domain, downplaying certain others and even providing new ones (BLACK, 1954; INDURKHYA, 1986, p. 518). If $F$ were a set containing members of ordered pairs that includes the pairs (bulldozer $\rightarrow$ Robert), (powerful $\rightarrow$ forceful), (clear $\rightarrow$ overcome), (rocks $\rightarrow$ opposing views), (obstacles $\rightarrow$ opponents) and $S$ were a set of sentences embracing $\left[2_{s}\right],\left[3_{s}\right],\left[4_{s}\right],\left[5_{s}\right]$, $\left[6_{s}\right]$ of the source domain, these would be transformed into $\left[2_{t}{ }^{\prime}\right],\left[3_{t}{ }^{\prime}\right],\left[4_{t}^{\prime}\right],\left[8_{t}^{\prime}\right]$ y $\left[9_{t}^{\prime}\right]$.

$\left[2_{\mathrm{t}}{ }^{\prime}\right]$ Robert is forceful (highlighting $2_{\mathrm{t}}$ )

$\left[3_{\mathrm{t}}{ }^{\prime}\right]$ Robert goes ahead overcoming opposing views (highlighting $3_{\mathrm{t}}$ )

$\left[4_{t}{ }^{\prime}\right]$ Robert has the power to overcome opponents (highlighting $4_{t}$ )

$\left[8_{\mathrm{t}}\right]$ Robert can be used to overcome opponents (new one, coming from $5_{\mathrm{s}}$ )

$\left[9_{\mathrm{t}}{ }^{\prime}\right]$ When Robert is used; the user becomes forceful (new one, coming from $6_{\mathrm{s}}$ )

$\left[2_{\mathrm{t}}{ }^{\prime}\right],\left[3_{\mathrm{t}}{ }^{\prime}\right],\left[4_{\mathrm{t}}{ }^{\prime}\right]$ are logical consequences of the target domain sentences, their information is included in the information represented by the sentences activated in the actual target domain $[2 \mathrm{t}],\left[3_{\mathrm{t}}\right],\left[4_{\mathrm{t}}\right]$. With $\left[2_{\mathrm{t}}{ }^{\prime}\right],\left[3_{\mathrm{t}}{ }^{\prime}\right],\left[4_{\mathrm{t}}{ }^{\prime}\right]$ nothing new is added to the target domain from the source domain but this target domain information is selected and reinforced by the relational similarities revealed by their alignment with the selected features in the source domain. As the information of $\left[5_{t}\right]$ is not selected, it is downplayed. In addition, when the description of the actual target domain is not aligned to the source domain in every feature, new information could be added to the target domain as it happens with $\left[8^{\prime}\right]$ and $\left[9^{\prime}{ }^{\prime}\right]$. The latter would be enriched showing how some similarities are created with metaphor, a proposal that authors such as Black (1954), Indurkhya (1986), Romero (1990/91) and Bowdle and Gentner (2005) have argued. In metaphorical interpretation, the target concept is described by means of some 
source concept-like relational properties which strengthen some properties that the concept already had and, in the more creative cases, by means of new properties that are added as a result of the analogical adjustment. PR leads us to the more appropriate way to carry out the matching of connected relations from source to target. The mapping is shaped guided by the search of the properties that will enable the hearer to obtain as many cognitive effects as possible following a path of least processing effort. In nonconventional metaphor, the cognitive gain that allows the hearer to get positive cognitive effects is achieved in part by the unusual conceptualization of some propositional constituent. This unusual conceptualization, which will be a constituent of the proposition intended, depends on a mapping that modifies the cognitive environment by downplaying, adding or strengthening certain properties of the target concept in an analogical way. This is peculiar of metaphor processing and recommends leaving behind a deflationary account of metaphor without any need to abandon PR.

The partial mapping above generates a metaphorically restructured target concept, ROBERT $_{x}{ }^{\mathrm{M}}$, characterised by $\left[2_{\mathrm{t}}{ }^{\prime}\right],\left[3_{\mathrm{t}}{ }^{\prime}\right],\left[4_{\mathrm{t}}{ }^{\prime}\right],\left[8_{\mathrm{t}}{ }^{\prime}\right]$ and $\left[9_{\mathrm{t}}{ }^{\prime}\right]$ that shows a conception about Robert which is analogically modified by some aspects of the concept BULLDOZER in the context of (8). ROBERT ${ }_{X}^{\mathrm{M}}$ represents one of the coherent possibilities for the restructuring of that target domain. ${ }^{17}$ This only will be a part of the context from which to interpret (8) when it permits the hearer to obtain enough positive cognitive effects to give good reasons for the devoted processing effort. The metaphorical restructuring of a concept is then guided not only by coherence but also by relevance so that the restructured target domain becomes the best context of interpretation.

The metaphorical restructured target concept enables the hearer to associate metaphorical ad hoc concepts or, as we prefer to call them, "metaphorical provisional meanings" with the vehicles of the metaphorical utterance. In the interpretation of (8), the metaphorical provisional meaning or the ad hoc concept of 'bulldozer', the vehicle of metaphor, is the meaning associated to 'Robert' in the metaphorically restructured target domain. ${ }^{18}$ We do not construct as its meaning an ad hoc concept with a wider application but with a different application. And what is associated to 'Robert' in $\operatorname{ROBERT}_{\mathrm{X}}{ }^{\mathrm{M}}$ is a conception of Robert as a forceful member of the department who takes his ideas ahead overcoming opposing views, who has the power to overcome opponents, who can be used for that purpose making the user also forceful, etc. The properties attributed to what we are talking about are properties-like and are said only about the topic we are talking about.

Then, the problem that does arise for most theorists on metaphor is how to account for the metaphorical interpretation of some properties of the source domain but without suggesting that they give way to properties that can be attributed to the denotation of the vehicle as well. From the interactive standpoint, for example,

\footnotetext{
${ }^{17}$ This metaphorically restructured target concept, nevertheless, cannot be used to interpret (3) because the context of (3) activates different encyclopaedic information for the source domain and thus it is not possible to elaborate the same mapping.

${ }^{18}$ The metaphorical concept the vehicle refers to, the concept that describes Robert metaphorically, is ROBERT $_{\mathrm{X}}{ }^{\mathrm{M}}$. The role of this concept is equivalent to the role of BULLDOZER* in RT. We prefer our notation because the kind of ad hoc concept that allows the understanding of metaphors does not describe the denotation of the metaphorical vehicle.
} 
interpreting metaphorically the encyclopaedic properties associated to the metaphorical vehicle is not to apply loosening again and again but to match relations from source to target domain. In this way, the first problem of loosening within loosening (and so on indefinitely) vanishes for them.

The second problem, the problem of how from metaphorical properties that were the result of a new loosening we can get properties attributed to the topic, does not arise either. The metaphorical interpretation of properties associated to the metaphorical vehicle can be explained from the mapping approach by considering that interpreting these properties metaphorically is but finding a structural alignment between domains so that a new meaning can be determined for these properties. And this meaning is determined taking into account the meaning of their counterparts according to $F$ in the target domain. Since in our proposal we do not speak of properties* but of the meaning of terms of the source domain, what we defend is that their meanings are fixed, for the occasion, by the meaning of their counterparts in the metaphorically restructured target domain. In (8), the meaning of 'powerful' is that of its analogical counterpart ('forceful') in the metaphorically restructured target domain, $\operatorname{ROBERT}_{\mathrm{X}}{ }^{\mathrm{M}}$.

The mapping is unavoidable because, appearances notwithstanding, correspondences between nonidentical, domain-specific properties need to be established for all non-conventional metaphorical utterances. And this is the case even in examples such as (4). When talking about a rough sea in a storm, (4) does not simply communicate an inaccuracy with respect to the quantity or the scope of the literal application of 'boiling' as it would happen in approximation and hyperbole which deal with (different degrees of) the temperature of water. There are no properties related to the concept expressed by its metaphorical vehicle that are also literally applied to the topic in the same sense. In the agitated cold sea water, there are no hollow globules that result from rapid heat. The chosen properties of the source domain have to change their meanings to be able to describe the topic and this is explained by an analogical process of mapping and not by means of undergoing a new loosening.

Finally, to know what encyclopaedic properties to choose from the source domain is not, as for relevance theorists, to consider the literal applicability of properties of the concept expressed by the metaphorical vehicle to the topic for examples such as (4) and (5) or the metaphorical applicability, understood as an applicability that requires loosening again, to the topic for examples such as (8). Rather it is to know what sentences of the source domain, $S$, are coherently transformed by the mapping. The selection of properties is made simply by choosing those literal properties of bulldozers that represent information whose structure can be aligned to say something parallel of Robert with properties that can be attributed to a human being. The common relational system is determined by the requirement that the transfer of information be coherent and the selection of mappable features is guided by the maximization of cognitive effects and by taking a path of least processing effort. Coherence and relevance are the inferential requirements of the mapping that permit to explain why the set $\left[2_{s}\right],\left[3_{s}\right],\left[4_{s}\right]$, $\left[5_{s}\right],\left[6_{s}\right]$ is selected for the interpretation of (8). In this mapping, for example, a correspondence between rocks and opposing views can be established because they play similar roles in their respective domain structures. The analogy aligns the role that rocks play in relation to the way they are cleared by the powerful machine and the role that 
opposing views play in relation to the way they are dismissed by the forceful member of the speaker's department in question.

In addition, as source domains represent the information not only of the encyclopaedic entry of concepts but also of the logical one, the mapping approach may explain the cases in which the logical property of the source concept is selected and mapped to the target, a property that, according to RT, should always be dropped. In our opinion, sometimes it is the logical property of the source concept that must be interpreted metaphorically. If we utter (5) in the context of a department elections of the head of department and Caroline is a candidate imposed by the actual head (for some reason or another, other people in the department have to accept it), the relevant feature to be mapped to the target domain is that of being the heir from the actual metaphorical king, the actual head of the department. It is the logical property, her status in a royal house, that should be transferred from source to target domain and not certain ways in which some princesses behave, as in the interpretation of the utterance of (5) explained above. The mapping can be established in different ways and using different pieces of information associated with the source concept, no matter whether this information is part of the logical or the encyclopaedic entry of the concept.

The metaphorical interpretation requires a special interpretive mechanism for the construction of metaphorical ad hoc concepts, that of an inferential mapping from a set of features of the source domain to a set of features of the target domain to produce a metaphorically restructured target domain that will be partially similar to the source domain. The metaphorically restructured target concept changes part of the interpretation context and is used to determine a new meaning at least for the metaphorical vehicle that can be the expression of an atomic concept or of a complex concept. Be that as it may, it stands for a metaphorical ad hoc concept or a metaphorical provisional meaning (ROMERO; SORIA, 2005) that makes this concept different from other pragmatic adjustments.

In this way we do not consider that an ad hoc concept construction account of creative metaphors is, as Carston has argued, inadequate and thus we do not need to claim that certain metaphors follow a different interpretation route. Metaphorical interpretation can be accounted for in a homogeneous way simply if we accept that the input of the ad hoc concept construction is not always a lexicalized atomic concept. ${ }^{19}$

In general, an ad hoc concept is one that is made up on the spot, that the speaker is most unlikely to have had ready-made before the occasion of the utterance (BARSALOU, 1983), and it may be ad hoc in different ways. On the one hand, as it is argued in RT, a lexicalized atomic concept may be taken as input to construct an ad hoc atomic concept through pragmatic derivation. Ad hoc atomic concepts are always nonliteral since they are the results of a pragmatic adjustment by narrowing, broadening or, as we also argue, by transfer. On the other, an ad hoc concept may be what is expressed by a complex phrase or by an extended text interpreted literally or not. In these cases, $a d$ hoc complex concepts can be literal or non-literal.

\footnotetext{
${ }^{19}$ This is not a possibility in relevance theory since, according to their lexical pragmatics; the input of the pragmatic adjustment is always a lexicalized atomic concept, something that would prevent the modulation of complex concepts.
} 
A literal ad hoc concept may be expressed by means of a complex phrase such as 'biggest fish in this backwater'. BIGGEST FISH IN THIS BACKWATER is literal in the sense that the complex expression that expresses it, the phrase, involves words that keep their encoded meaning in the composition of the meaning or complex ad hoc concept (ROMERO; SORIA, 2010b, 2012). If this ad hoc non-atomic concept were the intended concept, it would be literal although it clearly stands for a concept which is not readymade but constructed on the occasion of the utterance. But if we want to interpret (6), this literal ad hoc non-atomic concept does not form a part of the propositional content communicated by the speaker, in the same way as BULLDOZER does not form a part of the propositional content communicated by the speaker in (8). BIGGEST FISH IN THIS BACKWATER would be the concept expressed by the metaphorical vehicle and it is constructed, among other things, to be used as source concept, from which to elaborate a more ad hoc metaphorical concept which will be the concept communicated by the speaker. Morris seen provisionally from the conception of the biggest fish in this backwater provides a context of interpretation for (6) from which the literal ad hoc nonatomic concept, BIGGEST FISH IN THIS BACKWATER, is modulated as a whole and acquires a provisional metaphorical meaning. What should be highlighted is that the input of metaphorical interpretation is already an ad hoc concept and not a lexicalized one, as in the more simple cases of metaphor. This outlook is consistent with what Black pointed out about the information associated to the source domain, to wit, that the "[...] implications usually consist of "commonplaces" about the subsidiary subject [source domain], but may, in suitable cases, consist of deviant implications established ad hoc by the writer." (1954, p. 291, our emphasis).

This type of ad hoc complex concepts, represented by the source domain, are often used in the construction of ad hoc metaphorical concepts and, in this way, a certain type of highly creative metaphors (which can be exploited in extended ways) are typically produced. Sometimes a literal ad hoc concept may be expressed by means of an extended text such as (9), where 'that sea' points anaphorically to the literal ad hoc non-atomic concept AN APPARENTLY IMPERTURBABLE AND EVEN SEA WHICH APPEARANCES NOTWITHSTANDING CONTAINS FISH SWIMMING IN ITS DEPTHS.

(9) We know what the sea looks like from a distance: it is of one color, and level, and obviously cannot contain such creatures as fish. But if we look into the sea over the edge of a boat, we see a dozen colors, and depth below depth, and fish swimming in them. That sea is...

This ad hoc concept could be considered as the source concept in the mappings that permit to interpret the example of a creative and extended metaphor that appears if we continue reading (9), the literary text in which it is contextualised,

[That sea is] the English character - apparently imperturbable and even. The depths and the colors are the English romanticism and the English sensitiveness - we do not expect to find such things, but they exist. And - to continue my metaphor - the fish are the English emotions, which are always trying to get to the surface, but don't quite know how. For the most part we see them moving far below, distorted and obscure. Now and then they succeed and we exclaim, 'Why, the Englishman has emotions! He actually can feel!' 
Once the THE ENGLISH CHARACTER IS THAT SEA metaphor is elaborated, it can be exploited or extended coherently as it is the case when we consider how the literary text continues

\begin{abstract}
And occasionally we see that beautiful creature the flying fish, which rises out of the water altogether into the air and the sunlight. English literature is a flying fish. It is a sample of the life that goes on day after day beneath the surface; it is a proof that beauty and emotion exist in the salt, inhospitable sea.
\end{abstract}

(Foster's Abinger Harvest)

Now, the concept ENGLISH LITERATURE is shaped through the concept FLYING FISH. The metaphorical utterance of 'English literature is a flying fish' depends on the first metaphor. The source domain is extended to include the flying fish and the ad hoc concept THAT SEA is further specified as AN APPARENTLY IMPERTURBABLE AND EVEN SEA WHICH APPEARANCES NOTWITHSTANDING CONTAINS FISH SWIMMING IN ITS DEPTHS AND FROM WHICH A BEAUTIFUL CREATURE, THE FLYING FISH, RISES OUT OF THE WATER.

Metaphorical ad hoc concept construction is explained in the same way regardless of whether the metaphorical meaning is derived from just one lexicalized atomic concept, as in (3)-(5) and (8) or, from an ad hoc non-atomic concept that was represented either by a phrase or phrases, as in (6) and (7), or by an extended text, as in (9). The metaphorical utterance is usually more creative when the input of the mapping is not a ready-made concept. In these cases, the metaphorical concept that results from the ad hoc concept construction is particularly ad hoc. Nevertheless, examples whose source domains are ad hoc concepts may belong to a wide variety of texts and may appear in many genres, not just in literature. Unlike what seems to be suggested by RT, we do not think there is a direct relationship between poetic effects and creative metaphor. There are many conventional metaphors in literature and many creative metaphors in non-literary genres such as science or advertising. In our opinion, interpretation of creative metaphors is explained by a mapping in any genre and it is not advisable to talk about "literary or poetic metaphors" 20 even if the peculiar character of metaphors often contributes to the production of literary effects in a way that cannot be achieved by any other resource. This peculiar character of metaphor, however, can support other effects in science, for instance.

\title{
4 CONCLUSION
}

In this article we have argued that the mapping approach to metaphor offers an alternative to RT approach to metaphor as a case of loosening in a continuum. The problems of the latter are solved with the former, although it takes into account PR.

\footnotetext{
${ }^{20}$ In relation to this, Carston and Wearing (2011, p. 296) say: “(...) there is a distinction to be made, but it is not a distinction between two types of metaphor (the conversational and the literary); rather, it corresponds to two ways in which different metaphors (conversational or literary) may be processed," (our emphasis). Still, to account for the two ways, two different kinds of metaphor (conversational/literary) have to be discriminated. By contrast, in our opinion, metaphor is a phenomenon that may appear, as any other (literal, hyperbolic, ironic, etc.), in any genre (conversation, advertising, science, etc.) and its essential characteristics are found in all of them.
} 
When we claim that analogical reasoning is required in the construction of metaphorical ad hoc concepts we are not denying the role of PR in the interpretation of a metaphorical utterance, quite on the contrary, we have argued that the matching of properties in the relational system is achieved following the PR. What makes the mapping and loosening accounts different is the account of how the ad hoc concept is constructed: as a result of the pragmatic adjustment of concepts that act as source domains to get a different denotation (ROMERO; SORIA, 2007) or as a result of the pragmatic adjustment of encoded atomic concepts to get a wider denotation (WILSON; CARSTON, 2006). However, the introduction of analogical reasoning in the construction of the communicated metaphorical concept with a different denotation does not affect the general presumption of relevance or the relevance-guided comprehension heuristic. To interpret a metaphor, PR will be involved at least in the application of the metaphorical mechanism (a partial mapping from a conceptual domain into another) to yield a metaphorical restructured target domain that supplies the metaphorical ad hoc concepts (needed to get positive cognitive effects) following a path of least processing effort. The combined relevance-mapping approach on metaphor allows us to know how certain words in metaphorical utterances can change their meanings and what meanings they take on, and it shows that these meanings are not a mere combination of broadening/narrowing. The unitary account of lexical pragmatics should be rejected. In addition, the mapping approach permits a homogeneous explanation of the type of ad hoc concept construction that characterizes all cases of metaphorical interpretation; the most creative cases are examples whose metaphorical vehicles stand for ad hoc concepts that give way to others which are doubly ad hoc. This is an important finding which bears directly on Carston's $(2010 \mathrm{~b}, 318)$ question as to whether there is a property of 'metaphoricity' that all cases share and which distinguishes them from nonmetaphorical (literal or non-literal) interpretation.

\section{REFERENCES}

BARSAlOU, L. Ad Hoc Categories. Memories and Cognition, v. 11, p. 211-227, 1983.

BLACK, M. Metaphor. Proceedings of the Aristotelian Society, v. 55, p. 273-294, 1954.

More about Metaphor. Dialectica, v. 31, n. 3-4, p. 431-457, 1977.

BOWDLE, B.; GENTNER, D. The Career of Metaphor. Psychological Review, v. 112, p. 193-216, 2005.

CARSTON, R. Enrichment and Loosening: Complementary Processes in Deriving the Proposition Expressed. Linguistische Berichte, v. 8, p. 103-127, 1997.

Thoughts and Utterances: The Pragmatics of Explicit Communication. Oxford: Blackwell, 2002.

Explicit Communication and 'Free' Pragmatic Enrichment. In: SORIA, B.; ROMERO, E. (Eds.)

Explicit Communication: Essays on Robyn Carston's Pragmatics. Basingstoke: Palgrave Macmillan (Palgrave Studies in Pragmatics, Language and Cognition), 2010a, p. 217-285.

Metaphor: Ad Hoc Concepts, Literal Meaning and Mental Images. Proceedings of the Aristotelian Society, v. 110, n. 3, p. 295-321, 2010 b.

Word Meaning and Concept Expressed. The Linguistic Review, v. 29, n. 4, p. 607-623, 2012.

CARSTON, R.; WEARING, C. Metaphor, Hyperbole and Simile: A Pragmatic Approach. Language and Cognition, v. 3-2, p. 283-312, 2011.

FORCEVILLE, CH. Pictorial Metaphor in Advertising. London/New York: Routledge, 1996. 
GENTNER, D. Are Scientific Analogies Metaphors? In: MIALL, D. S. (Ed.). Metaphor: Problems and Perspectives. Brighton: Harvester Press, 1982, p. 106-132. 1983. Structure-Mapping: A Theoretical Framework for Analogy. Cognitive Science, v. 7, p. 155-170,

GENTNER, D.; BOWDLE, B.; WOLFF, P.; BORONAT C. Metaphor is like analogy. In: GENTNER, D.; HOLYOAK, K. J.; KOKINOW, B. N. (Eds.). The Analogical Mind: Perspectives from Cognitive Science. Cambridge (MA), MIT Press, 2001.

GOODMAN, N. Metaphor as Moonlighting. Critical Inquiry, v. 6, n. 1, p. 125.130.

INDURKHYA, B. Constrained Semantic Transference: A Formal Theory of Metaphor. Synthese, v. 68, p. 515-551, 1986. 1992.

Metaphor and Cognition: An Interactionist Approach. Dordrecht: Kluwer Academic Publishers,

KITTAY, E. F.: Metaphor. Oxford: Clarendon Press, 1987.

LAKOFF; G.; JOHNSON, L. Metaphors We Live by. Chicago: Univ. of Chicago Press, 1980.

PILKINGTON, A. Metaphor Comprehension: Some Questions for Current Accounts in Relevance Theory. In: ${ }^{\text {SORIA }}$, B.; ${ }^{\text {ROMERO }}$, E. (E $\mathrm{E}^{\mathrm{d}} \mathrm{s}^{\text {). }}$ Explicit communication: Essays on Robyn Carston's Pragmatics. Basingstoke: Palgrave Macmillan (Palgrave Studies in Pragmatics, Language and Cognition), 2010, p. 156-172.

RICHARDS, I. A. The Philosophy of Rhetoric. London: Oxford University Press, 1936.

ROMERO, E. Las metáforas y el significado metafórico. La balsa de la Medusa, v. 15-16-17, p. 59-80, 1990/91.

ROMERO, E.; SORIA, B. Stylistic Analysis and Novel Metaphor. Pragmalingüística, v. 5/6, p. 373-89, 1997/98.

Cognitive Metaphor Theory Revisited. Journal of Literary Semantics, v. 34, p. 1-20, 2005.

. A View of Novel Metaphor in the Light of Recanati’s Proposals. In: FRÁPOLLI, M. J. (Ed.). Saying, Meaning and Referring: Essays on François Recanati's Philosophy of Language. Basingstoke: Palgrave Macmillan (Palgrave Studies in Pragmatics, Language and Cognition), 2007, p. 145-159.

. Introduction: Explicit Communication and Relevance Theory Pragmatics. SORIA, B.; ROMERO, E. (Eds.) Explicit communication: Essays on Robyn Carston's Pragmatics. Basingstoke: Palgrave Macmillan (Palgrave Studies in Pragmatics, Language and Cognition), 2010a, p. 1-24.

Phrasal Pragmatics in Robyn Carston's Programme. In: SORIA, B.; ROMERO, E. (Eds.)Explicit Communication: Essays on Robyn Carston's Pragmatics. Basingstoke: Palgrave Macmillan (Palgrave Studies in Pragmatics, Language and Cognition), 2010b, p. 183-198.

Construcción conceptual ad hoc e interpretación metafórica. Forma y Función, v. 25, n. 2, p. $\overline{217-245}, 2012$.

El significado metafórico: Un reto para las teorías del significado. In: PÉREZ-CHICO, D. (Ed.). Perspectivas de la filosofia del lenguaje. Zaragoza: Prensas de la Universidad de Zaragoza (Colecc. Humanidades), 2013, p. 521-562.

SPERBER, D.; WILSON, D. Relevance: Communication and Cognition. Oxford: Blackwell, 1986/1995.

A Deflationary Account of Metaphor. In: Gibbs, R. W. (Ed.). The Cambridge Handbook of Metaphor and Thought. New York: CUP, 2008, p. 84-108.

TENDAHL, M.; GIBBS, R. Complementary Perspectives on Metaphor: Cognitive Linguistics and Relevance Theory. Journal of Pragmatics, v. 40, p. 1823-1864, 2008.

WILSON, D.; CARSTON, R. A Unitary Approach to Lexical Pragmatics: Relevance, Inference and Ad Hoc Concepts. In: BURTON-ROBERTS, N. (Ed.). Pragmatics. London: Palgrave, 2007, p. 230-260.

Metaphor and the 'Emergent Property' Problem: A Relevance-Theoretic Treatment. In: The Baltic International Yearbook of Cognition, Logic and Communication, v. 3. Kansas: New Praire Press, p. 1-40, 2008. A previous version of this article is Metaphor, relevance and the 'emergent property' issue. Mind and Language, v. 21, n. 3, p. 404-433, 2006. 
Recebido em 25/05/14. Aprovado em 23/09/14.

Título: Teoria da relevância e Metáfora

Autores: Esther Romero e Belén Soria

Resumo: Neste artigo, mostramos a evolução da abordagem da metáfora na teoria da relevância e questionamos a posição deflacionária da metáfora, defendida desde o início como uso vago dentro de um continuum. Na versão atual da teoria da relevância, os usos vagos não só transmitem implicaturas, mas também explicaturas nas quais os conceitos ad hoc aparecem (CARSTON, 2002, 2010a; SPERBER; WILSON, 2008). Estes conceitos, no caso da metáfora, geram o problema das propriedades emergentes que, segundo eles, é resolvido tendo em conta que um uso vago pode ser incluído em outro uso vago (WILSON; CARSTON, 2008). Além disso, os casos mais criativos têm de ser explicados considerandose uma rota de interpretação diferente daquela da construção de conceitos ad hoc (CARSTON, 2010b). Esses movimentos geram novos problemas e, dessa maneira, argumentamos que a interpretação metafórica pode ser mais bem explicada recorrendo a conceitos metafóricos ad hoc que resultam de um mapeamento parcial de um domínio conceitual para outro (ROMERO; SORIA, 2005).

Palavras-chave: Teoria da Relevância. Metáfora. Conceito Ad Hoc. Mecanismo Metafórico. Analogia. Derivação Pragmática.

Título: Teoría de la relevancia y metáfora

Autores: Esther Romero y Belén Soria

Resumen: En este artículo mostramos la evolución del enfoque de la metáfora en la teoría de la relevancia y cuestionamos su posición deflacionaria de la metáfora, defendida desde el inicio, como vaguedad en un continuo. En la versión actual de la teoría, los usos vagos no solo comunican implicaturas sino también explicaturas en las que aparecen conceptos ad hoc (CARSTON, 2002, 2010a; SPERBER; WILSON, 2008). Estos, en el caso de la metáfora, causan el problema de las propiedades emergentes que se intenta solucionar defendiendo que un uso vago puede incluirse en otro uso vago (WILSON; CARSTON, 2008). Además, los casos más creativos requieren una ruta de interpretación diferente a la de construcción de conceptos ad hoc (CARSTON, 2010b). Estas modificaciones generan nuevos problemas y, por ello, defendemos que la interpretación metafórica puede explicarse mejor recurriendo a conceptos metafóricos ad hoc que resultan de una aplicación parcial desde un dominio conceptual a otro (ROMERO; SORIA, 2005).

Palabras-clave: Teoría de la Relevancia. Metáfora. Concepto Ad Hoc. Mecanismo Metafórico. Analogía. Derivación Pragmática. 